\title{
Additive Mutagenic Effects of DNA Damages Induced by Multiple Mutagens at Virtually Non-mutagenic Dose Level of Each
}

\author{
Toshihiro Ohta ${ }^{1}$ \\ School of Life Sciences, Tokyo University of Pharmacy and Life Sciences, Tokyo, Japan
}

(Received June 1, 2007; Revised August 30, 2007; Accepted September 4, 2007)

DNA damages provoked by the six mutagens (furylframide, $\mathrm{MX}$, 4-nitroquinoline $\mathrm{N}$-oxide, sodium azide, 1 nitropyrene, and captan) used in the present study have been known to subject to the nucleotide excision repair system. Therefore, they induced base-substitution mutations much more efficiently in Salmonella typhimurium TA100 (hisG46, rfa, uvrB/pKM101), a strain deficient in nucleotide excision repair, than in TA1975P (hisG46, rfa/pKM101). Doses below undetectable level in the reverse mutation assay were selected as those that were apparently mutagenic to the repair-deficient strain TA100 but not to the repair-proficient strain TA1975P in this study. Then, the six mutagens were mixed at virtually nonmutagenic dose level of each and a possible combined mutagenic effect was investigated. A significant and reproducible increase in the number of revertants in TA1975P was observed with combined mutagens. The results suggest that DNA adduct formation at virtually non-mutagenic dose level was additive, with the total amount reflecting the mutagenicity.

Key words: threshold, nucleotide excision repair, combined mutagenicity, additive effect, Salmonella typhimurium

\section{Introduction}

Recent studies argue for the existence of a biologically meaningful threshold dose below which induced DNA damage is repaired and consequently no induced mutations are detected. The concept of "biological threshold" by Kirsch-Volders et al. is "the chemical is present, and can interact with the target, but no adverse consequence is induced"' (1). It was originally defined by Seiler as "Real (or biological) threshold" (2). The terms of real threshold or biological threshold, however, are sometime confused with true threshold. In this paper, therefore, I used "virtually non-mutagenic dose" to explain the dose below which most of induced DNA damages would be correctly repaired and consequently no induction of reverse mutations was detected in the DNA repair-proficient bacterial strain (3). Occurrence of DNA damage could be proved by evidence that mutagenicity at the dose was detected in the corresponding DNA repair-deficient bacterial strain. The existence of virtually non-mutagenic doses was suggested by Sofuni et al. (3) on several mutagens, such as 4-nitroquinoline $N$-oxide (NQ), 3-chloro-4-(dichloromethyl)-5-hydroxy2(5H)-furanone (MX), and furylfuramide (AF), which showed that reverse mutations are not induced in wildtype strains for nucleotide excision repair capability at concentrations that induce them in the repair-deficient (uvr) mutant strains. The contribution of DNA repair in dose responses at very low doses is also reported on methylating mutagens $(4,5)$.

Assuming that a biologically meaningful threshold dose indeed exists for DNA-targeting mutagens, it is important to clarify whether multiple mutagens at virtually non-mutagenic dose of each would exhibit additive mutagenicity, because most environmental exposures involve complex mixtures of chemicals. In my previous study (6), I reported the additive mutagenic effects of 6 heterocyclic amines in S. typhimurium TA1978P, a nucleotide excision repair-proficient strain. When the 6 heterocyclic amines were mixed together at virtually non-mutagenic dose level of each for TA1978P, a significant increase in the number of revertants was observed in the strain, suggesting the total amount of DNA adducts reflecting the mutagenicity. In the present study, possible additive effects were investigated in combination of structurally different mutagens.

\section{Materials and Methods}

Chemicals, bacterial strains, and media: Mutagens and their source are listed in Table 1. AF, MX, NQ, 1-nitropyrene (NP), and captan (CA) were dissolved in dimethyl sulfoxide (DMSO, Wako Pure

\footnotetext{
${ }^{1}$ Correspondence to: Toshihiro Ohta, School of Life Sciences, Tokyo University of Pharmacy and Life Sciences, 1432-1 Horinouchi, Hachioji, Tokyo 192-0392, Japan. Tel: +81-42-676-7093, Fax: +8142-676-7081, E-mail: ohta@1s.toyaku.ac.jp
} 
Table 1. Mutagens used in this study

\begin{tabular}{|c|c|c|c|c|c|}
\hline Abbr. & Chemical name (Common name) & CAS No. & Source & Purity & Ref.* \\
\hline $\mathrm{AF}$ & 2-(2-furyl)-3-(5-nitro-2-furyl)acrylamide, (Furylfuramide) & $3688-53-7$ & Wako & $>98 \%$ & $\begin{array}{ll}\text { A: } & (7) \\
\text { R: } & (8)\end{array}$ \\
\hline MX & 3-chloro-4-(dichloromethyl)-5-hydroxy-2(5H)-furanone & $77439-76-0$ & Wako & STD & $\begin{array}{lr}\text { A: } & (9) \\
\text { R: } & (10)\end{array}$ \\
\hline NQ & 4-nitroquinoline $\mathrm{N}$-oxide & $56-57-5$ & Kasei & $>98 \%$ & $\begin{array}{l}\text { A: } \\
\text { R: }(11)\end{array}$ \\
\hline $\mathrm{AZ}$ & sodium azide & $26628-22-8$ & Naca & $>98 \%$ & $\mathrm{R}:(13)$ \\
\hline NP & 1-nitropyrene & $5522-43-0$ & Kasei & $>98 \%$ & $\begin{array}{ll}\text { A: } & (14) \\
\text { R: } & (15)\end{array}$ \\
\hline $\mathrm{CA}$ & $N$-(trichloromethylthio)-4-cyclohexane-1,2-dicarboximide, (Captan) & $133-06-2$ & Wako & STD & $\begin{array}{l}\text { A: }(16) \\
\text { R: }\end{array}$ \\
\hline
\end{tabular}

Kasei: Tokyo Kasei Kogyo Co. (Tokyo), Naca: Nacalai Tesque, Inc. (Kyoto), Wako: Wako Pure Chemical Industries Ltd., (Tokyo), STD: Standard grade for analysis

${ }^{*}$ References regarding DNA adduct formation (A) and contribution of nucleotide excision repair to DNA damages (R)

Chemical Industries Ltd., Tokyo). Sodium azide (AZ) was dissolved in sterile Milli-Q water. S. typhimurium strains TA1975P (hisG46, rfa/pKM101) and TA100 (hisG46, $u v r B, r f a / \mathrm{pKM} 101$ ) were used for the reverse mutation assays. TA1975P was constructed by conjugation between TA1975 (hisG46, rfa) (18) and Escherichia coli WP2000 (trpE, pro)/pKM101 (mucAB, amp) $(19,20)$. TA1975 and WP2000/pKM101 were mixed in nutrient broth and incubated overnight at $37^{\circ} \mathrm{C}$ without shaking. TA1975 carrying plasmid pKM101 (named TA1975P) was selected as an ampicillin-resistant colony on a minimal glucose agar plate with histidine. TA1975 and TA100 were obtained from Prof. Bruce N. Ames (CA, USA). Bacteria were cultured in nutrient medium (Oxoid, No.2) at $37^{\circ} \mathrm{C}$ with shaking. Minimal glucose agar plates consisted of Vogel-Bonner E medium supplemented with $2 \%$ glucose and $1.5 \%$ agar (18). Top agar $(0.6 \%$ agar and $0.5 \% \mathrm{NaCl})$ contained $0.05 \mathrm{mM} \mathrm{D}$ biotin and $0.05 \mathrm{mM}$ L-histidine.

Reverse mutation assay: The $\mathrm{His}^{+}$reversion assay $(6,18)$ was conducted with $S$. typhimurium strains TA1975P and TA100. The bacteria were precultured overnight in nutrient broth. Aliquots of $0.1 \mathrm{~mL}$ of bacterial culture and $0.005-0.02 \mathrm{~mL}$ of a mutagen solution were added to $0.5 \mathrm{~mL}$ of sodium phosphate buffer $(0.1$ $\mathrm{M}, \mathrm{pH}$ 7.4). The total volume of DMSO in each test tube was adjusted to $0.1 \mathrm{~mL}$. After preincubation at $37^{\circ} \mathrm{C}$ for $20 \mathrm{~min}$, treated cells were poured onto minimal glucose agar plates with $2 \mathrm{~mL}$ molten top agar. His ${ }^{+}$ revertants were counted following $48 \mathrm{~h}$ incubation at 37 ${ }^{\circ} \mathrm{C}$. Experiments investigating individual dose-response curves included 4 plates for each dose of mutagen. Experiments investigating combined effects were conducted 3 times to confirm reproducibility with 6,10 , or 12 plates for each group. The Dunnett test was used for statistical analysis.

\section{Results}

To determine the "virtually non-mutagenic doses" in TA1975P, dose-response curves were obtained with wide dose range of $0.001-0.5 \mu \mathrm{g} / \mathrm{plate}$ for AF, $0.002-1$ $\mu \mathrm{g} /$ plate for MX, $0.01-5 \mu \mathrm{g} /$ plate for NQ, and $0.1-20$ $\mu \mathrm{g} /$ plate for AZ, NP and CA. The response at low doses was hidden within the background variability. Virtually non-mutagenic response (less than the value of mean + SD of the concurrent negative control in TA1975P) was observed below $0.02 \mu \mathrm{g} /$ plate for AF, $0.05 \mu \mathrm{g} /$ plate for $\mathrm{MX}, 0.2 \mu \mathrm{g} /$ plate for NQ, $0.2 \mu \mathrm{g} /$ plate for AZ, 0.5 $\mu \mathrm{g} /$ plate for NP, and $1 \mu \mathrm{g} /$ plate for CA (Table 1). Then the mutagenic responses were checked with the strain TA100 $(u v r B)$ to confirm the occurrence of induction of DNA damages at the corresponding low doses. Significant increases in the number of revertants above the spontaneous level starting at $0.0005 \mu \mathrm{g} / \mathrm{plate}$ (AF), $0.002 \mu \mathrm{g} /$ plate $(\mathrm{MX}), \quad 0.002 \mu \mathrm{g} /$ plate $(\mathrm{NQ}), \quad 0.01$ $\mu \mathrm{g} /$ plate (AZ), $0.1 \mu \mathrm{g} /$ plate (NP), and $0.05 \mu \mathrm{g} /$ plate (CA) in TA100 were detected (Table 1). The lowest mutagenic doses of those mutagens in TA1975P were 100 to 500 times the lowest mutagenic doses in TA100. These results suggested that the existence of virtually non-mutagenic dose level below which mutagenicity is not evident at all in TA1975P due to a function of nucleotide excision repair.

As a virtually non-mutagenic dose in TA1975P for each mutagen, $0.01 \mu \mathrm{g} /$ plate for AF, 0.02 for MX, 0.1 for NQ, 0.2 for AZ, 0.2 for NP, and 0.5 for CA were selected for further experiments (underlined dose in Table 2). When the 6 mutagens were combined at the above doses and assayed the mutagenicity with TA1975P (6 plates per each dose), a significant increase in the number of revertants was observed (Fig. 1). Since the observed increase was less than two-fold over the background level, confirmation experiments were repeated with 10 and 12 plates per each dose. The significant increase was reproducible in 3 experiments. The 
Table 2. Dose-response of mutagens in the strains TA1975P and its $u v r B$ derivative TA 100

\begin{tabular}{|c|c|c|c|c|c|}
\hline \multirow{3}{*}{ Mutagen } & \multirow{3}{*}{$\begin{array}{c}\text { Dose } \\
\mu \mathrm{g} / \text { plate }\end{array}$} & \multicolumn{4}{|c|}{ Number of revertants/plate } \\
\hline & & \multicolumn{2}{|c|}{ TA1975P $(n=4)$} & \multicolumn{2}{|c|}{ TA100 $(n=4)$} \\
\hline & & mean & SD & mean & SD \\
\hline \multirow[t]{14}{*}{$\mathrm{AF}$} & 0 & 11.8 & 2.2 & 103.8 & 11.9 \\
\hline & 0.00005 & - & - & 120.0 & 6.7 \\
\hline & 0.0001 & - & - & 132.8 & 6.1 \\
\hline & 0.0002 & - & - & 134.0 & 5.3 \\
\hline & 0.0005 & - & - & 145.3 & $17.7^{*}$ \\
\hline & 0.001 & 9.8 & 1.7 & 159.0 & $21.8^{* *}$ \\
\hline & 0.002 & 9.5 & 2.6 & 223.0 & $21.0^{* *}$ \\
\hline & 0.005 & 10.8 & 2.9 & 367.8 & $32.3^{* *}$ \\
\hline & 0.01 & 13.3 & 4.3 & 693.5 & $26.1^{* *}$ \\
\hline & $\overline{0.02}$ & $\overline{11.5}$ & 1.0 & & \\
\hline & 0.05 & 21.0 & 5.4 & & \\
\hline & 0.1 & 37.5 & $7.5^{* *}$ & & \\
\hline & 0.2 & 82.8 & $2.1^{* *}$ & & \\
\hline & 0.5 & 182.5 & $17.7^{* *}$ & & \\
\hline \multirow[t]{14}{*}{ MX } & 0 & 11.8 & 2.2 & 103.8 & 11.9 \\
\hline & 0.0001 & - & - & 108.0 & 16.7 \\
\hline & 0.0002 & - & - & 111.5 & 14.3 \\
\hline & 0.0005 & - & - & 124.0 & 3.6 \\
\hline & 0.001 & - & - & 126.8 & 9.1 \\
\hline & 0.002 & 10.3 & 3.6 & 149.3 & $10.1^{*}$ \\
\hline & 0.005 & 12.8 & 2.6 & 233.8 & $14.8^{* *}$ \\
\hline & 0.01 & 10.8 & 2.1 & 356.3 & $39.1^{* *}$ \\
\hline & 0.02 & 10.8 & 3.9 & 603.0 & $33.7^{* *}$ \\
\hline & $\overline{0.05}$ & $\overline{12.3}$ & 1.3 & & \\
\hline & 0.1 & 19.0 & 3.9 & & \\
\hline & 0.2 & 28.3 & $5.4^{* *}$ & & \\
\hline & 0.5 & 62.8 & $7.1^{* *}$ & & \\
\hline & 1 & 141.3 & $7.4^{* *}$ & & \\
\hline \multirow[t]{14}{*}{ NQ } & 0 & 11.8 & 2.2 & 98.3 & 12.5 \\
\hline & 0.0005 & - & - & 114.8 & 9.1 \\
\hline & 0.001 & - & - & 111.0 & 3.9 \\
\hline & 0.002 & - & - & 127.8 & $12.4^{*}$ \\
\hline & 0.005 & - & - & 137.0 & $15.8^{* * *}$ \\
\hline & 0.01 & 10.8 & 5.1 & 197.0 & $15.5^{* *}$ \\
\hline & 0.02 & 10.3 & 2.8 & 277.5 & $10.7^{* *}$ \\
\hline & 0.05 & 11.0 & 2.6 & 277.5 & $10.7^{* *}$ \\
\hline & 0.1 & 12.3 & 3.2 & 520.5 & $19.2^{* *}$ \\
\hline & $\overline{0.2}$ & $\overline{11.0}$ & 6.0 & & \\
\hline & 0.5 & 19.5 & 1.3 & & \\
\hline & 1 & 42.3 & $2.9^{* *}$ & & \\
\hline & 2 & 135.5 & $18.5^{* *}$ & & \\
\hline & 5 & 467.3 & $10.6^{* *}$ & & \\
\hline \multirow[t]{15}{*}{$\mathrm{AZ}$} & 0 & 10.3 & 1.5 & 105.5 & 11.1 \\
\hline & 0.001 & - & - & 125.5 & 2.6 \\
\hline & 0.002 & - & - & 118.3 & 18.7 \\
\hline & 0.005 & - & - & 140.0 & 6.3 \\
\hline & 0.01 & - & - & 147.3 & $23.1^{*}$ \\
\hline & 0.02 & - & - & 157.0 & $21.6^{* *}$ \\
\hline & 0.05 & - & - & 208.8 & $10.3^{* *}$ \\
\hline & 0.1 & 10.5 & 1.0 & 258.5 & $24.5^{* *}$ \\
\hline & 0.2 & 11.3 & 3.9 & 389.5 & $34.5^{* *}$ \\
\hline & $\overline{0.5}$ & $\overline{14.0}$ & 3.6 & 497.5 & $24.8^{* *}$ \\
\hline & 1 & 20.0 & 3.7 & & \\
\hline & 2 & 25.5 & $3.4^{* *}$ & & \\
\hline & 5 & 31.0 & $4.7^{* *}$ & & \\
\hline & 10 & 50.8 & $7.9^{* *}$ & & \\
\hline & 20 & 66.5 & $8.5^{* *}$ & & \\
\hline
\end{tabular}

Table 2. (continued)

\begin{tabular}{|c|c|c|c|c|c|}
\hline \multirow{3}{*}{ Mutagen } & \multirow{3}{*}{$\begin{array}{c}\text { Dose } \\
\mu \mathrm{g} / \text { plate }\end{array}$} & \multicolumn{4}{|c|}{ Number of revertants/plate } \\
\hline & & \multicolumn{2}{|c|}{ TA1975P $(n=4)$} & \multicolumn{2}{|c|}{ TA100 $(n=4)$} \\
\hline & & mean & SD & mean & SD \\
\hline \multirow[t]{12}{*}{ NP } & 0 & 13.0 & 2.6 & 98.3 & 12.5 \\
\hline & 0.01 & - & - & 109.8 & 12.9 \\
\hline & 0.02 & - & - & 118.3 & 8.0 \\
\hline & 0.05 & - & - & 126.5 & 21.3 \\
\hline & 0.1 & 13.8 & 5.7 & 175.3 & $16.5^{* *}$ \\
\hline & 0.2 & 11.0 & 2.0 & 275.3 & $10.9^{* *}$ \\
\hline & $\overline{0.5}$ & $\overline{14.2}$ & 4.1 & $\overline{663.3}$ & $31.4^{* *}$ \\
\hline & 1 & 18.3 & 5.0 & & \\
\hline & 2 & 24.5 & 2.5 & & \\
\hline & 5 & 35.5 & $8.4^{* *}$ & & \\
\hline & 10 & 48.3 & $13.9^{* *}$ & & \\
\hline & 20 & 45.0 & $6.5^{* *}$ & & \\
\hline \multirow[t]{13}{*}{$\mathrm{CA}$} & 0 & 11.2 & 2.3 & 98.3 & 12.5 \\
\hline & 0.005 & - & - & 96.3 & 12.6 \\
\hline & 0.01 & - & - & 101.3 & 16.6 \\
\hline & 0.02 & - & - & 115.8 & 9.5 \\
\hline & 0.05 & - & - & 130.8 & $20.8^{*}$ \\
\hline & 0.1 & 9.8 & 3.3 & 160.5 & $19.8^{* *}$ \\
\hline & 0.2 & 11.0 & 2.2 & 208.0 & $8.0^{* *}$ \\
\hline & $\underline{0.5}$ & 10.8 & 2.4 & 352.8 & $16.8^{* *}$ \\
\hline & $\overline{1}$ & $\overline{10.8}$ & 2.2 & & \\
\hline & 2 & 14.4 & 1.8 & & \\
\hline & 5 & 28.8 & $9.1^{* *}$ & & \\
\hline & 10 & 31.3 & $10.7^{* *}$ & & \\
\hline & 20 & 22.3 & $4.6^{* *}$ & & \\
\hline
\end{tabular}

${ }^{*}, \mathrm{p}<0.05 ;{ }^{* *}, \mathrm{p}<0.01$ (Dunnett test)

increased level by combined treatment was almost equal to those induced by each mutagen at 6-times higher dose (for example, $0.05 \mu \mathrm{g} /$ plate $\mathrm{AF}$ or $0.1 \mu \mathrm{g} /$ plate $\mathrm{MX}$ in Table 2). These results suggest that the DNA damages induced by each mutagen at virtually non-mutagenic dose were additive and the total amount of DNA damage (adduct formation) reflected collective mutagenicity.

\section{Discussion}

Nucleotide excision repair system plays a crucial role in removing many types of DNA adducts formed by chemical mutagens. Formation of "bulky" base adducts would generate significant distortion of the DNA helix. The nucleotide excision repair process includes recognition of helical distortion in duplex DNA followed by dual incisions of the damaged DNA strand near the site of lesion, excision of an oligonucleotide fragment containing DNA damage, and repair synthesis of DNA (21). This process can occur in an error-free way so that the damaged DNA is repaired accurately. DNA damages induced by the 6 mutagens used in the present study are repaired by the nucleotide excision repair system $(8,10,12,13,15,17)$. Adducts at $\mathrm{C} 8$ of guanine, $N^{2}$ of guanine, and $N^{6}$ of adenine produced by 

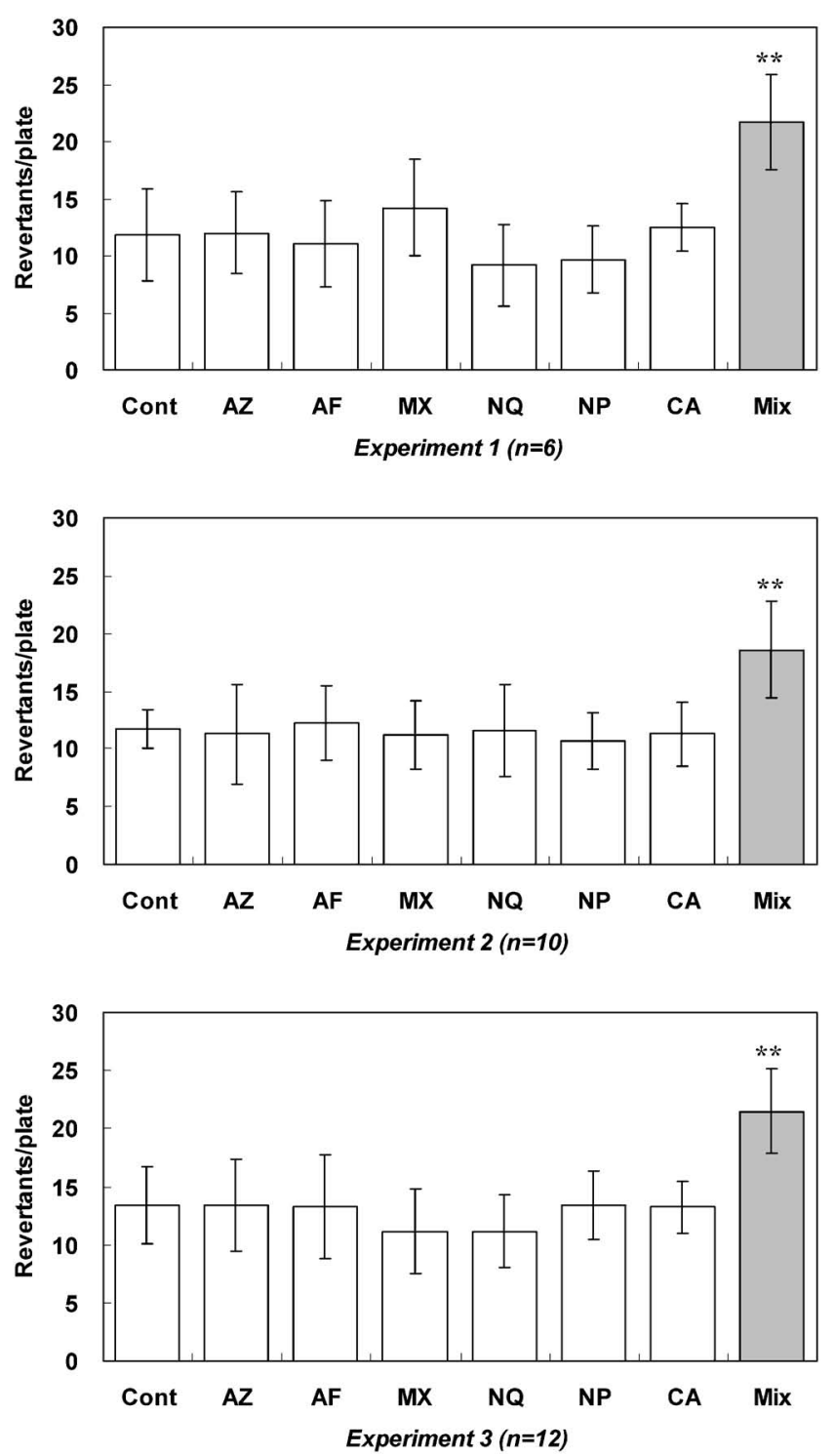

Fig. 1. Additive effect of 6 mutagens at virtually non-mutagenic doses in repair-proficient strain TA1975P. Dose of AF, MX, NQ, AZ, $\mathrm{NP}$, and CA were $0.01,0.02,0.1,0.2,0.2$, and $0.5 \mu \mathrm{g} /$ plate, respectively. Combined treatment ( ray bar) with mixture of 6 mutagens at above doses caused significant increase ( ${ }^{* *}, \mathrm{p}<0.01$ by Dunnett test). Data are the means of 6,10 , and 12 plates, respectively, in experiment 1, 2, and 3. Error bars mean standard deviation (SD).

NQ-treatment have been identified (11). NP induced DNA adduct to the C8 position of guanine (14). MXguanosine adduct (9), and DNA adduct formation by AF (7) and CA (16) have been reported. AZ mutagenesis is mediated through a metabolic intermediate (azidoalanine) in bacteria and plant cells. Although very little is known about the interaction of the intermediate with DNA, many observations suggests that the initial AZinduced lesion causes a major DNA helix distortion recognizable by the excision-repair endonucleases (13).

Since the nucleotide excision repair system recognizes distortion of the DNA helix, but not adduct molecule itself, it is important to investigate the combined effect of multiple mutagens even if their doses are virtually nonmutagenic level. The present results as well as my previous work with 6 heterocyclic amines (6) suggest that DNA adduct formation at virtually non-mutagenic doses was additive, with the total amount reflecting the mutagenicity. One of the possible explanations for additive effect might be the formation of closely spaced opposing lesions. If two closely spaced adducts on complementary strands were introduced by the same mutagen, such adduct could not be repaired by the nucleotide excision repair because of the presence of the lesion in the template strand. Two extremely closely spaced opposing lesions would be also induced by different mutagens in the combined treatment with multiple mutagens. In contrast to the additive effects on reverse mutations in the present study, synergistic effects by multiple clastogens in mouse micronucleus assay has been reported (22). Further investigations on the combined effects may be needed with different endpoint for genotoxicity.

The absence of a threshold has been assumed for genotoxic carcinogens in risk evaluation. The nonthreshold model was first proposed for radiation, on the basis of the one-hit model of action for ionizing radiation, and then extended to chemical mutagens. On the other hand, a concept for the existence of a biologically meaningful threshold has been discussed on genotoxic carcinogens $(3,23)$. The present study would be expected to provide useful data for this argument. As described in the result, $0.02 \mu \mathrm{g} /$ plate of $\mathrm{MX}, 0.1 \mu \mathrm{g} /$ plate of NQ, $0.2 \mu \mathrm{g} /$ plate of AZ and NP, and $0.5 \mu \mathrm{g} /$ plate of $\mathrm{CA}$ used for the combined treatment seems to be almost equivalent to $0.01 \mu \mathrm{g} /$ plate of $\mathrm{AF}$. Thus the dose of combined effects would be calculated as $0.06(0.01 \times 6)$ $\mu \mathrm{g} /$ plate of AF. Similarly, it would be calculated as 0.12 $(0.02 \times 6) \mu \mathrm{g} /$ plate of MX, $0.6(0.1 \times 6) \mu \mathrm{g} /$ plate of NQ, $1.2(0.2 \times 6) \mu \mathrm{g} /$ plate of $\mathrm{AZ}$ and NP, and $3.0(0.5 \times 6)$ $\mu \mathrm{g} /$ plate of CA. These calculated doses for each mutagen showed almost same mutagenic effect (Table 1 for $0.05 \mu \mathrm{g} /$ plate AF, $0.1 \mu \mathrm{g} /$ plate MX, $0.5 \mu \mathrm{g} /$ plate NQ, 1 $\mu \mathrm{g} /$ plate of $\mathrm{AZ}$ and $\mathrm{NP}$, and $5 \mu \mathrm{g} /$ plate of $\mathrm{CA}$ ) as that in the combined treatment $\left(20.3,18.6\right.$ and $21.5 \mathrm{His}^{+}$ /plate in Fig.1). Based on above calculation, it may be possible to estimate virtually non-mutagenic dose even in the combined treatment. For example, if there are 20 kinds of mutagens at doses equivalent to $0.001 \mu \mathrm{g} / \mathrm{plate}$ $\mathrm{AF}$, combined mutagenic effect is estimated as 0.02 $(0.001 \times 20) \mu \mathrm{g} /$ plate $\mathrm{AF}$, indicating the dose is within virtually non-mutagenic level for TA1975P.

Acknowledgments: This work was supported by Grants-in-Aid for Scientific Research from the Food Safety Commission of Japan. 


\section{References}

1 Kirsch-Volders M, Aardema M, Elhajouji A. Concepts of threshold in mutagenesis and carcinogenesis. Mutat Res. 2000; 464: 3-11.

2 Seiler JP. Apparent and real threshold: a study on two mutagens, In: Scott D, Bridges BA, Sobels FH, editors. Progress in Genetic Toxicology. Elsevier/North-Holland Biochemical Press. 1977. pp. 233-8.

3 Sofuni T, Nohmi T, Ohta T, Hayashi M. Genotoxicity: Is a threshold concept applicable to evaluate the mutagenic activity of DNA-targeting substances? Environ Mutagen Res. 2005; 27: 61-73. (in Japanese)

4 Sofuni T, Hayashi M, Nohmi T, Matsuoka A, Yamada M, Kamata E. Semi-quantitative evaluation of genotoxic activity of chemical substances and evidence for a biological threshold of genotoxic activity. Mutat Res. 2000; 464: 97-104.

5 Jenkins GJS, Doak SH, Johnson GE, Quick E, Waters EM, Parry JM. Do dose response thresholds exist for genotoxic alkylating agents? Mutagenesis. 2005; 20: 389-98.

6 Ohta T. Mutagenic activity of a mixture of heterocyclic amines at doses below the biological threshold level of each. Genes Environ. 2006; 28: 181-4.

7 Lambert IB, Chin TA, Bryant DW, Gordon AJ, Glickman BW, McCalla DR. The mutational specificity of 2(2-furyl)-3-(5-nitro-2-furyl)acrylamide (AF2) in the lacI gene of Escherichia coli. Carcinogenesis. 1991; 12: 29-34.

8 Nunoshiba T, Nishioka H. Protective effect of R-factor plasmid pKM101 on lethal damage by UV and chemical mutagens in $E$. coli strains with different DNA-repairing capacities. Mutat Res. 1984; 141: 135-9.

9 Franzen R, Tanabe K, Morita M. Isolation of a MXguanosine adduct formed at physiological conditions. Chemosphere. 1998; 36: 2803-8.

10 Meier JR, Blazak WF, Knohl RB. Mutagenic and clastogenic properties of 3-chloro-4-(dichloromethyl)-5hydroxy-2(5H)-furanone: a potent bacterial mutagen in drinking water. Environ Mol Mutagen. 1987; 10: 411-24.

11 Galiegue-Zouitina S, Bailleul B, Loucheux-Lefebvre MH. Adducts from in vivo action of the carcinogen 4hydroxyaminoquinoline 1-oxide in rats and from in vitro reaction of 4-acetoxyaminoquinoline 1-oxide with DNA and polynucleotides. Cancer Res. 1985; 45: 520-5.

12 Kondo S, Ichikawa H, Iwo K, Kato T. Base-change mutagenesis and prophage induction in strains of Escherichia coli with different DNA repair capacities. Genetics. 1970; 66: 187-217.

13 Kleinhofs A, Smith JA. Effect of excision repair on azideinduced mutagenesis. Mutat Res. 1976; 41: 233-40.

14 Bacolod MD, Krishnasamy R, Basu AK. Mutagenicity of the 1-nitropyrene-DNA adduct $N$-(deoxyguanosin-8-yl)1-aminopyrene in Escherichia coli located in a nonrepetitive CGC sequence. Chem Res Toxicol. 2000;13: 523-8.

15 Luo C, Krishnasamy R, Basu AK, Zou Y. Recognition and incision of site-specifically modified $\mathrm{C} 8$ guanine adducts formed by 2 -aminofluorene, $N$-acetyl-2-aminofluorene and 1-nitropyrene by UvrABC nuclease. Nucleic Acids Res. 2000; 28: 3719-24.

16 Snyder RD. Effects of captan on DNA and DNA metabolic processes in human diploid fibroblasts. Environ Mol Mutagen. 1992; 20: 127-33.

17 Barrueco C, de la Pena E. Mutagenic evaluation of the pesticides captan, folpet, captafol, dichlofluanid and related compounds with the mutants TA102 and TA104 of Salmonella typhimurium. Mutagenesis. 1988; 3: 467-80.

18 Maron D, Ames BN. Revised methods for the Salmonella mutagenicity test. Mutat Res. 1983; 113: 173-215.

19 Ohta T, Watanabe-Akanuma M, Tokishita S, Yamagata H. Mutation spectra of chemical mutagens determined by $\mathrm{Lac}^{+}$reversion assay with Escherichia coli WP3101PWP3106P tester strains. Mutation Res. 1999; 440: 59-74.

20 Watanabe-Akanuma M, Inaba Y, Ohta T. Mutagenicity of UV-irradiated maltol in Salmonella typhimurium. Mutagenesis. 2007; 22: 43-7.

21 Friedberg EC, Walker GC, Siede W, Wood RD, Schultz RA, Ellenberger T, editors. Nucleotide excision repair. In: DNA Repair and Mutagenesis, 2nd ed. ASM Press, Washington DC; 2006. pp.227-66.

22 Suzuki T, Hayashi M, Hakura A, Asita AO, Kodama Y, Honma M, Sofuni T. Combination effects of clastogens in the mouse peripheral blood micronucleus assay. Mutagenesis. 1995; 10: 31-6.

23 Henderson L, Albertini S, Aardema M. Thresholds in genotoxicity responses. Mutat Res. 2000; 464: 123-8. 